\title{
Regulatory mechanisms of testosterone-stimulated song in the sensorimotor nucleus HVC of female songbirds
}

Falk Dittrich*, Claudia Ramenda, Doris Grillitsch, Carolina Frankl-Vilches, Meng-Ching Ko, Moritz Hertel, Wolfgang Goymann, Andries ter Maat and Manfred Gahr

\begin{abstract}
Background: In male birds, influence of the sex steroid hormone testosterone and its estrogenic metabolites on seasonal song behavior has been demonstrated for many species. In contrast, female song was only recently recognized to be widespread among songbird species, and to date, sex hormone effects on singing and brain regions controlling song development and production (song control nuclei) have been studied in females almost exclusively using domesticated canaries (Serinus canaria). However, domesticated female canaries hardly sing at all in normal circumstances and exhibit only very weak, if any, song seasonally under the natural photoperiod. By contrast, adult female European robins (Erithacus rubecula) routinely sing during the winter season, a time when they defend feeding territories and show elevated circulating testosterone levels. We therefore used wild female European robins captured in the fall to examine the effects of testosterone administration on song as well as on the anatomy and the transcriptome of the song control nucleus HVC (sic). The results obtained from female robins were compared to outcomes of a similar experiment done in female domesticated canaries.

Results: Testosterone treatment induced abundant song in female robins. Examination of HVC transcriptomes and histological analyses of song control nuclei showed testosterone-induced differentiation processes related to neuron growth and spacing, angiogenesis and neuron projection morphogenesis. Similar effects were found in female canaries treated with testosterone. In contrast, the expression of genes related to synaptic transmission was not enhanced in the HVC of testosterone treated female robins but was strongly up-regulated in female canaries. A comparison of the testosterone-stimulated transcriptomes indicated that brain-derived neurotrophic factor (BDNF) likely functions as a common mediator of the testosterone effects in HVC.

Conclusions: Testosterone-induced singing of female robins correlated with cellular differentiation processes in the HVC that were partially similar to those seen in the HVC of testosterone-treated female canaries. Other modes of testosterone action, notably related to synaptic transmission, appeared to be regulated in a more species-specific manner in the female HVC. Divergent effects of testosterone on the HVC of different species might be related to differences between species in regulatory mechanisms of the singing behavior.
\end{abstract}

Keywords: Songbird, Soft song, European robin, Canary, Microarray, Transcriptome, Testosterone, Song control nucleus, HVC

\footnotetext{
*Correspondence: dittrich@orn.mpg.de

Max Planck Institute for Ornithology, Department of Behavioural

Neurobiology, Eberhard-Gwinner Strasse, Haus 6a, Seewiesen 82319,

Germany
}

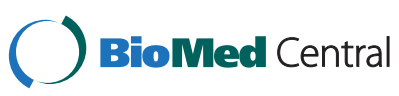

(c) 2014 Dittrich et al.; licensee BioMed Central Ltd. This is an Open Access article distributed under the terms of the Creative Commons Attribution License (http://creativecommons.org/licenses/by/4.0), which permits unrestricted use, distribution, and reproduction in any medium, provided the original work is properly credited. The Creative Commons Public Domain Dedication waiver (http://creativecommons.org/publicdomain/zero/1.0/) applies to the data made available in this article, unless otherwise stated. 


\section{Background}

Seasonal changes in bird song are mediated by testosterone and associated with neuroanatomical modifications in the song control system [1], a network of forebrain song control nuclei [2]. Both song control nuclei HVC (sic) and RA (robust nucleus of the arcopallium) express the androgen receptor [3]. These nuclei constitute the motor pathway of the song control system that controls song production [4-6]. The HVC is involved in the control of stereotyped song timing $[7,8]$ and processing of syntactic information [9]. The anterior forebrain pathway that is necessary for sensorimotor song learning [10] includes a second population of HVC projection neurons that innervate the basal ganglia-like Area $\mathrm{X}$ (proper name) and feed back on RA via two further brain areas.

Female song is a behavior particularly common in songbird species from tropical latitudes, but there is increasing evidence that it also occurs in bird species inhabiting temperate zones [11-14]. In some songbird species such as the canary [15-25], chaffinch [26,27], blackbird [28], Oregon and Mexican Juncos [29], white-crowned sparrow [30-32], yellowhammer [33] and song sparrow [34], adult female singing occurs rarely but testosterone has been shown to stimulate singing activity. Likewise, in female starlings that sing at high rates while having low plasma testosterone levels [35] song rate increases in response to testosterone administration [36-39]. However, there is no evidence that natural circulating testosterone levels are involved in regulating female song for these species. In contrast, female European robins display robust song when they defend feeding territories in winter, during which they also show elevated plasma testosterone levels [40]. Female European robins are therefore an excellent model species with which to study cellular processes in the song control nuclei that parallel testosterone-induced song development. Since female robin song development is related to establishing winter territories the anatomical and molecular events underlying song development are difficult to study in the field. For this study we caught female robins in the fall and mimicked experimentally high levels of testosterone in a controlled setting.

In European robins, only males express high-amplitude full songs, both for courtship and territory defense, during the breeding season whilst both sexes may use highamplitude full song to defend their feeding territories in autumn and winter [41-45]. Full song is characterized by harmonic overtones and syllables with frequencies above $15 \mathrm{kHz}$. Low-amplitude songs are produced by both sexes as continuous streams of notes $[42,44]$ that we will refer to as "soft song". Female robins normally produce soft songs only in autumn and not during the breeding season [44].

So far, the cellular and molecular mechanisms involved in testosterone-dependent seasonal changes in the female song control system have been predominantly studied in canaries. Testosterone treatment increases the volumes of HVC, RA, MAN and Area $\mathrm{X}$ in adult female canaries [19,25,46-50], most likely by stimulating neuronal processes including cell spacing and growth of somata and dendrites, as well as increasing the number of HVC neurons and glia cells [19,20,50-55]. Testosterone-induced angiogenesis in the HVC of female canaries [56] is associated with an up-regulation of the vascular endothelial growth factor (VEGF), the VEGF receptor kinase insert domain receptor (KDR) and brain-derived neurotrophic factor (BDNF) expression [57]. Although the blocking of VEGF receptor activity does not inhibit a testosteroneinduced increase in HVC volumes it does prevent androgenic induction of song development in adult female canaries [58]. The up-regulation of BDNF expression in endothelial cells of the HVC supports testosteronedependent recruitment and survival of new neurons into HVC $[57,59]$. Furthermore, an effect of sex steroid hormones on the recruitment and survival of new neurons in the HVC was also found in the adult female European starling [60].

In spring, adult female European robins have low endogenous plasma testosterone levels [61] and usually do not sing [42]. However, female robins start singing once testosterone levels are elevated following treatment with testosterone [61] or naturally in autumn and winter [42]. Here, we studied female robins that were caught in the fall, when HVC was expected to develop testosterone responsiveness, to gain information about cellular and molecular effects of testosterone on female song control nuclei. We supported our results on a genome-wide gene expression analysis of the HVC by conducting immunofluorescence and in-situ hybridization experiments. Further, we compared the testosterone-induced changes of the European robin HVC transcriptome with the testosterone effect on the HVC transcriptome of the female canary. In the female canary, one testosteronestimulated gene in the HVC, the neurotrophin BDNF, affects cell recruitment and survival [57] and is required for the development of male-like high song pattern such as syllable numbers [58] or number of high-speed tours [62]. Thus, in addition to a general analysis of gene networks we focused in particular on testosterone-induced changes in BDNF expression and in potential BDNFdriven gene networks in the HVC.

\section{Results}

\section{Increased song in females}

In female robins testosterone treatment first stimulated the production of soft song: while daily soft song rate was low in the week before testosterone pellet implantation (mean \pm SEM, both groups combined: $0.3 \pm 0.1 \mathrm{~min}$ ) and did not differ between the control and testosterone group 
(Kruskal-Wallis Test; $\mathrm{n}=6, \mathrm{p}=0.872$ ), five out of six testosterone-treated female robins produced streams of soft notes beginning two days after implantation. By the third day of testosterone treatment daily soft song production had increased in testosterone-treated robins $(7.6 \pm$ $11.9 \mathrm{~min})$ as compared to controls $(0.2 \pm 0.1 \mathrm{~min})(\mathrm{p}<0.01$; residual maximum likelihood (REML) method with period of treatment as random factor followed by Tukey HSD with $\alpha=0.05$ for effect of treatment) (Figure 1A). The increase in song activity resulted in the development of a continuous stream of soft notes (Figure 1B). Mean song pitch increased significantly between days three and seven (mean \pm SEM: $2420 \pm 82 \mathrm{~Hz}$ for controls and $2735 \pm$ $84 \mathrm{~Hz}$ for testosterone females; Kruskal-Wallis Test; $\mathrm{n}=6$, $\mathrm{p}=0.0374$ ). An increase of higher frequencies due to increased sound pressure levels could explain this finding. Total production of soft song during the last three days before female robins were sacrificed was significantly higher in testosterone-treated females compared to the time-matched controls (mean \pm SEM: $0.008 \pm 0.006 \mathrm{~min}$ for controls and $146.8 \pm 53.3 \mathrm{~min}$ for testosterone females; Kruskal-Wallis Test; $n=6, p=0.0037$ ). Occurrence of first loud song notes of testosterone-treated robins (Figures $1 \mathrm{C}$ and Additional file 1: Figure S1) were used as indicators for their ability to produce sound pressures that we observed in crystallized songs of our testosterone-treated female canaries.

Testosterone-induced song development is a welldescribed behavior of female canaries [24,53]. While our control female canaries did not sing at all, songs of testosterone-treated birds were highly structured (mean syllable repertoire: 10.3 syllables; mean tour length: $1.11 \mathrm{sec}$ ) with three out of six birds displaying fast frequency modulated syllables [24] in $15.94 \%$ of all tours.

\section{Morphological changes in the song control system of female robins}

For testosterone-induced effects on the adult female robins' song control system, we looked at the neuroanatomy of the song control system and the size of the syrinx, the vocal organ. As expected from findings in adult female canaries [19,50-54], testosterone increased the size of song control nuclei in adult female robins (Figure 2). The volumes of HVC and RA as determined from Nisslstained sections were found to have tripled after two weeks of testosterone treatment (mean \pm SEM: $0.081 \pm$ $0.012 \mathrm{~mm}^{3}$ for control-HVC and $0.271 \pm 0.043 \mathrm{~mm}^{3}$ for testosterone-HVC; $0.079 \pm 0.012 \mathrm{~mm}^{3}$ for control-RA
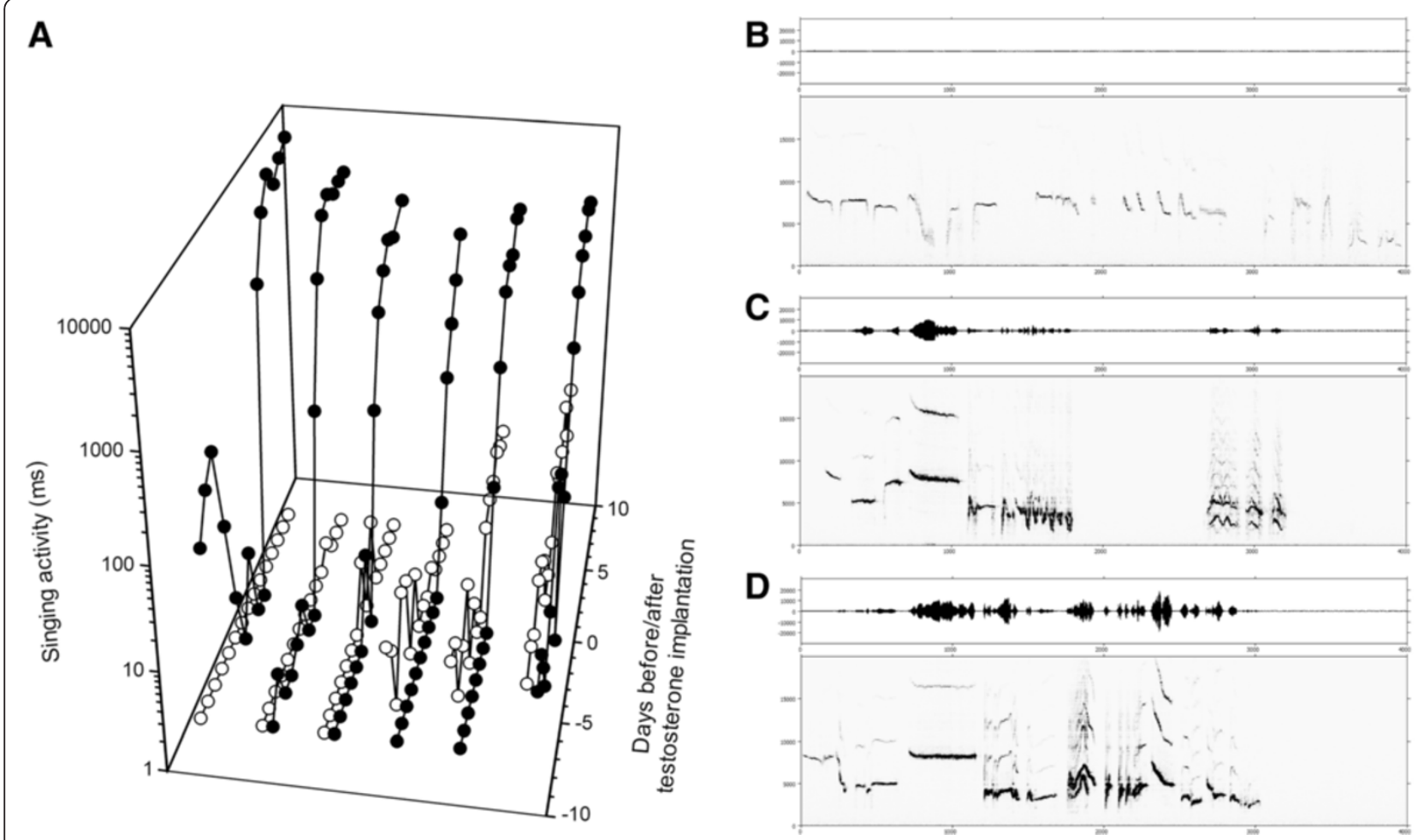

Figure 1 Testosterone stimulated the production of soft song in female European robins. (A) Daily singing activity was recorded from testosterone $(\bullet)$ and time-matched control (o) birds. Testosterone pellets were subcutaneously implanted at day zero. (B-D) Sound waves (amplitude (analog/digital arbitrary units) over time (ms)) are shown in the upper panels and sonograms are presented in the lower panels (frequency ( $\mathrm{Hz}$ ) over time $(\mathrm{ms})$ ). For female robin \# 14 (B) details of soft song after seven days of testosterone treatment and (C) first high amplitude song phrases after eleven days are depicted. In (D), a small portion of full song obtained from an adult male robin is depicted. 

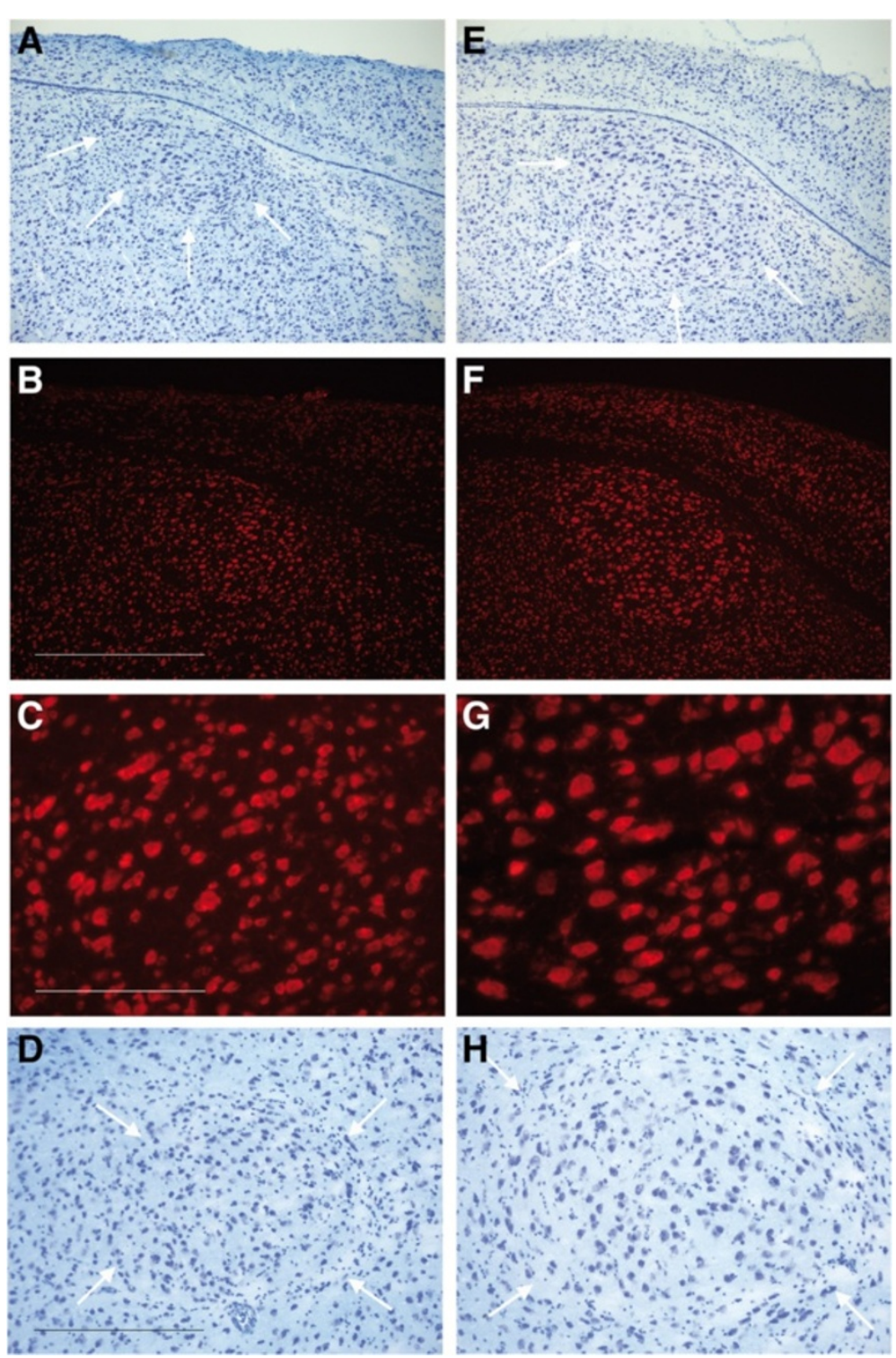

Figure 2 Testosterone stimulated the growth of song control nuclei in female European robins. Photomicrographs are shown for the HVC $(\mathbf{A}-\mathbf{C}, \mathbf{E}-\mathbf{G})$ and the RA (D, H) after staining with $0.1 \%$ thionin (Nissl staining: A, D, E, H) and an anti-NeuN antibody (B, C, F, G), respectively. Sagittal forebrain cryostat sections were obtained from control (left panels) and testosterone (right panels) female robins. Arrows indicate the border of a song control nucleus; scale bars represent $100 \mu \mathrm{m}$ ( $\mathbf{C}$ for $\mathbf{C}$ and $\mathbf{G}$ ) and $500 \mu \mathrm{m}$ (B for $\mathbf{B}$ and $\mathbf{F} ; \mathbf{D}$ for $\mathbf{D}$ and $\mathbf{H}$ ), respectively. Note that the testosterone treatment increased the volume (A, B vs E, F; D vs H), neuron size and spacing (C vs $\mathbf{G})$ of a song control nucleus.

and $0.26 \pm 0.022 \mathrm{~mm}^{3}$ for testosterone-RA) ( $\mathrm{t}$-test: $\mathrm{n}=4$, $\mathrm{t}=4.7337, \mathrm{p}=0.0031$ for $\mathrm{HVC}$ and $\mathrm{p}=0.0039$ for $\mathrm{RA})$.

Reduced density of NeuN-immunopositive cells after testosterone treatment (Figure 2: C vs G) suggested testosterone-induced neuronal spacing in HVC. In line with this observation we found spacing of nuclear signals in HVC to increase on average by a factor of 1.3 after two weeks of testosterone treatment (t-test; $\mathrm{n}=4$, $\mathrm{t}=2.853, \mathrm{p}=0.0291$ ) as determined by a counterstain with 4',6-diamidino-2-phenylindole-dihydrochloride (DAPI) (Additional file 2: Figure S2). Circumcellular structures in
HVC and RA were immunopositive for NEFM (neurofilament, medium polypeptide; Figure 3), which is a marker gene for HVC [63] that was found to be up-regulated by testosterone in our transcriptome study (Additional file 3: Table S1 and Additional file 4: Table S2). Since the testosterone treatment resulted in an enlargement of HVC volume but did not reduce the distribution of the anti-NEFM signal (Figure 3A,B vs E, F) HVC neuropil seemed to extend in response to the hormone. In register with this observation we determined the percentage of the NEFMimmunopositive area in $\mathrm{HVC}$ of control and testosterone 

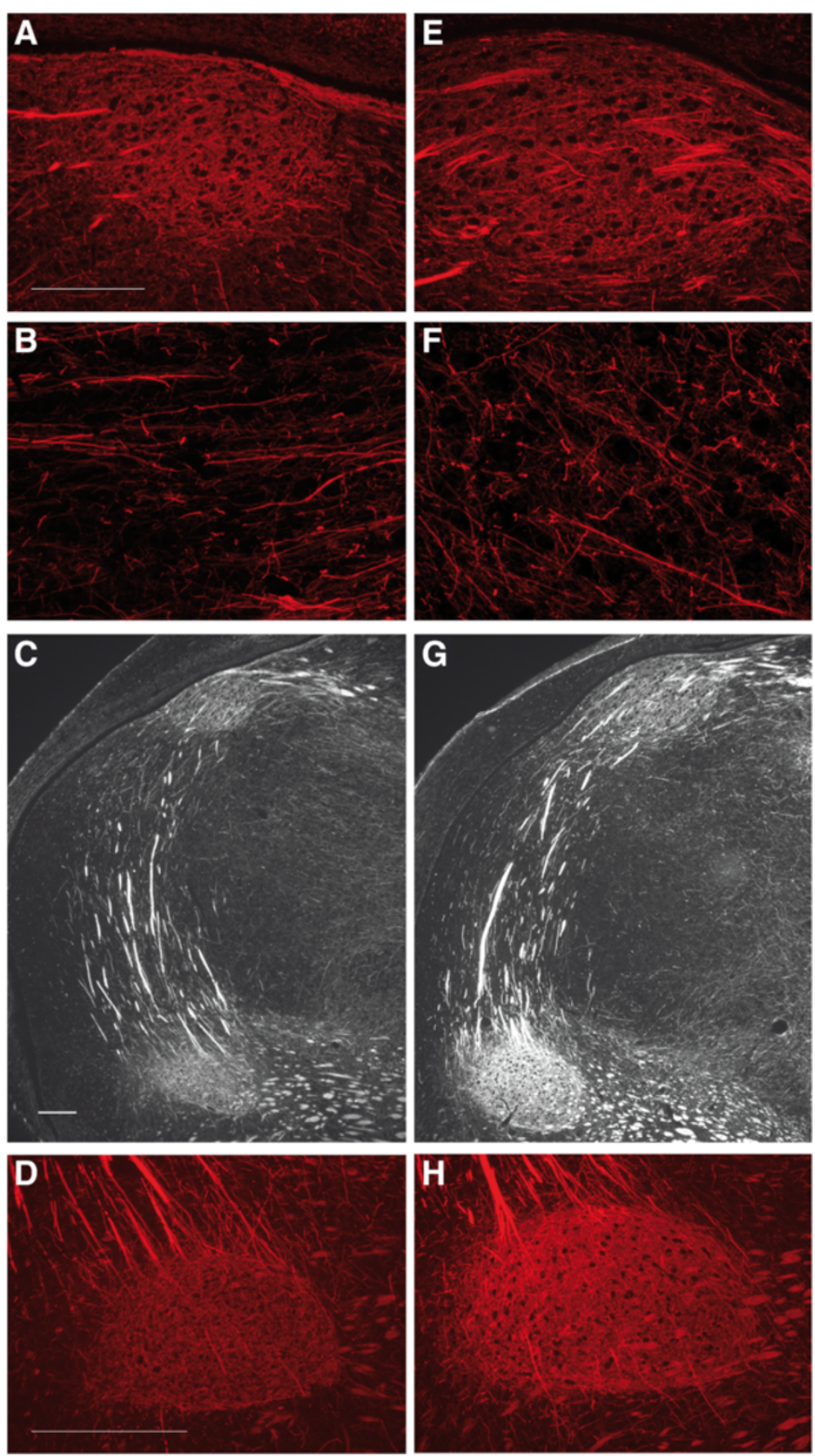

Figure 3 Testosterone stimulated the expression of neurofilament in the song control nuclei of female European robins.

Photomicrographs are shown for the HVC (A, B, E, F), the RA (D, H) and for the caudal forebrain $(\mathbf{C}, \mathbf{G})$ after anti-neurofilament immunofluorescence staining. Scale bars represent $100 \mu \mathrm{m}$ (A for $\mathbf{A}$ and $\mathbf{E} ; \mathbf{C}$ for $\mathbf{C}$ and $\mathbf{G}$ ) and $250 \mu \mathrm{m}(\mathbf{D}, \mathbf{H})$, respectively. Sagittal cryostat sections were obtained from control (left panels) and testosterone (right panels) female robins. Please note an expansion of circumcellular, neurofilament-immunopositive structures after testosterone treatment.

birds to be identical after two weeks of testosterone treatment (mean \pm SEM: $57.1 \pm 1.6 \%$ for control HVC and $57.9 \pm 2.9 \%$ for testosterone-HVC; t-test on the difference: $\mathrm{n}=4, \mathrm{t}=0.2397, \mathrm{p}=0.8186$ ). Strong anti-NEFM immunostaining of the RA after testosterone treatment (Figure 3C, $\mathrm{D}$ vs $\mathrm{G}, \mathrm{H}$ ) went together with testosterone-induced neuron projection morphogenesis in HVC (see below), but did not necessarily indicate enhanced RA innervations by HVC projection neurons.

In agreement with the effect of testosterone on the vocal organ in other songbird species [64-67], we detected syrinx growth in the adult female robins after 
testosterone treatment. Syrinx of control and testosterone females exhibited significant differences in both wet weight (mean \pm SEM: $6.4 \pm 0.3 \mathrm{mg}$ for control and $9.6 \pm$ $0.5 \mathrm{mg}$ for testosterone females; $\mathrm{p}=0.0062$ ) and protein content as determined by a standard Bradford assay (mean \pm SEM: $0.245 \pm 0.018 \mathrm{mg}$ for control and $0.335 \pm$ $0.013 \mathrm{mg}$ bovine serum albumin equivalents for testosterone females; $\mathrm{p}=0.0106$; Kruskal-Wallis Test, $\mathrm{n}=6$, $\mathrm{p}=0.025$ after Bonferroni correction).

\section{Testosterone effects on female HVC transcriptome}

Transcriptome analysis of the female robin HVC revealed that the expression levels of 219 genes were increased after testosterone treatment by a factor of at least 1.6, while 281 genes were down-regulated by the same factor (Additional file 3: Table S1A). In the HVC of female canaries, the expression levels of 877 genes were up-regulated and decreased for 2127 genes after testosterone-treatment when applying the same criterion. In female robins, the expression of $50 \%$ of the up- and $66 \%$ of the downregulated genes was concordantly changed by testosterone in female canaries as well (Additional file 5: Figure S3A).

For the bioinformatic analyses of the transcriptome results we used information available for human orthologous genes. In the following, we will first describe testosterone-induced changes in cellular and biological processes in the HVC of adult female robins. Subsequently, we will compare the biological processes in the HVC that were affected by testosterone between female robins and canaries, focusing on processes that were enriched in the up- and down-regulated genes as determined by GeneRanker (Genomatix).

\section{Effects in robins}

Most of the genes that were strongly (> 1.8-fold) affected by testosterone showed an up-regulation in the HVC of female robins while down-regulated genes exhibited moderate expression changes (>1.6-fold; Additional file 3: Table S1B). We consistently identified processes related to cell locomotion and adhesion, neuron projection morphogenesis and axonal guidance, as well as blood vessel development to be most significantly overrepresented in the up-regulated genes (g:profiler; DAVID; GePS; IPA). Further, the largest network of up-regulated genes that we discovered by pathway analysis (GePS) (Additional file 6: file Figure S4) included well-known angiogenic growth factors like VEGFA (vascular endothelial growth factor A) and PGF (placental growth factor), as well as the VEGFA receptor KDR (VEGF receptor 2; [68]) and co-receptor NRP1 (neuropilin 1; [69]). Further, for most of the other genes that participated in this network, roles in blood vessel development have been reported. In addition, signaling processes involving the up-regulated ligands TNFSF13B (tumor necrosis factor (ligand) superfamily, member 13b), WNT7B (wingless-type
MMTV integration site 7B) and HEG1 (heart of glass homolog 1) as well as the receptor MET (for hepatocyte growth factor) might have mediated pro-angiogenic testosterone effects [70-76]. Putative negative regulators of angiogenesis that were stimulated by testosterone were CXCL14 (chemokine ligand 14; [77]) and TNFRSF1 (tumor necrosis factor receptor superfamily, member 1A), which may have mediated the activity of up-regulated angiostatic extracellular matrix protein THBS1 (thrombospondin 1 ; [78,79].

In an additional functional transcriptome analysis we considered gene information obtained from PubMed and GenCards and limited the analysis to genes that showed at least two-fold changes in expression; as a consequence mainly up-regulated genes were included in this analysis. A majority (46\%) of the strongly responding genes affected cellular communication through processes like signal transduction, cell-cell/ECM interaction and growth factor activity (Additional file 4: Table S2).

\section{Comparison of effects in robins and canaries}

As expected from the diverging numbers of testosteroneregulated genes in the two bird species, we obtained unequal numbers of affected GO-terms (Additional file 7: Table S3; up-regulated: 285 for robin, 479 for canary; down-regulated: 150 for robin, 271 for canary). Most significantly overrepresented common GO-terms (up-regulated: 149; downregulated: 56) in the group of up-regulated genes was blood vessel development (GO:0001568; $\mathrm{p}=8.58 \mathrm{E}-10$ ) and in the group of down-regulated genes was cell projection organization (GO:0030030; $\mathrm{p}=1.2 \mathrm{E}-07$ ). Angiogenesis and recruitment of newborn neurons are processes known to occur in the adult female canary HVC in response to testosterone and are considered to be closely linked [56]. Our transcriptome study of the HVC from testosteronedependent female canaries revealed that neurogenesis (GO:0022008; $\mathrm{p}=2.65 \mathrm{E}-08$ ) was much more likely to be overrepresented in the up-regulated genes than angiogenesis (GO:0001525; $\mathrm{p}=3.64 \mathrm{E}-04$ ). In contrast, up-regulated genes in the HVC of our testosterone-treated adult female robins were more likely associated with blood vessel development (see above) and angiogenesis ( $\mathrm{p}=2.98 \mathrm{E}-$ 05) than with neurogenesis $(\mathrm{p}=8.78 \mathrm{E}-04)$ (Additional file 7: Table S3).

Regarding explicitly neuronal processes in the HVC of female robins, we found that testosterone induced the expression of genes that were most likely associated with the development of neuronal projections, the development and differentiation of neurons and with neurogenesis, although at a slightly lower probability (Figure 4). In female canaries, the same neuronal processes were affected by testosterone at relatively comparable probabilities. In contrast, synaptic transmission was enhanced by testosterone at a relative 


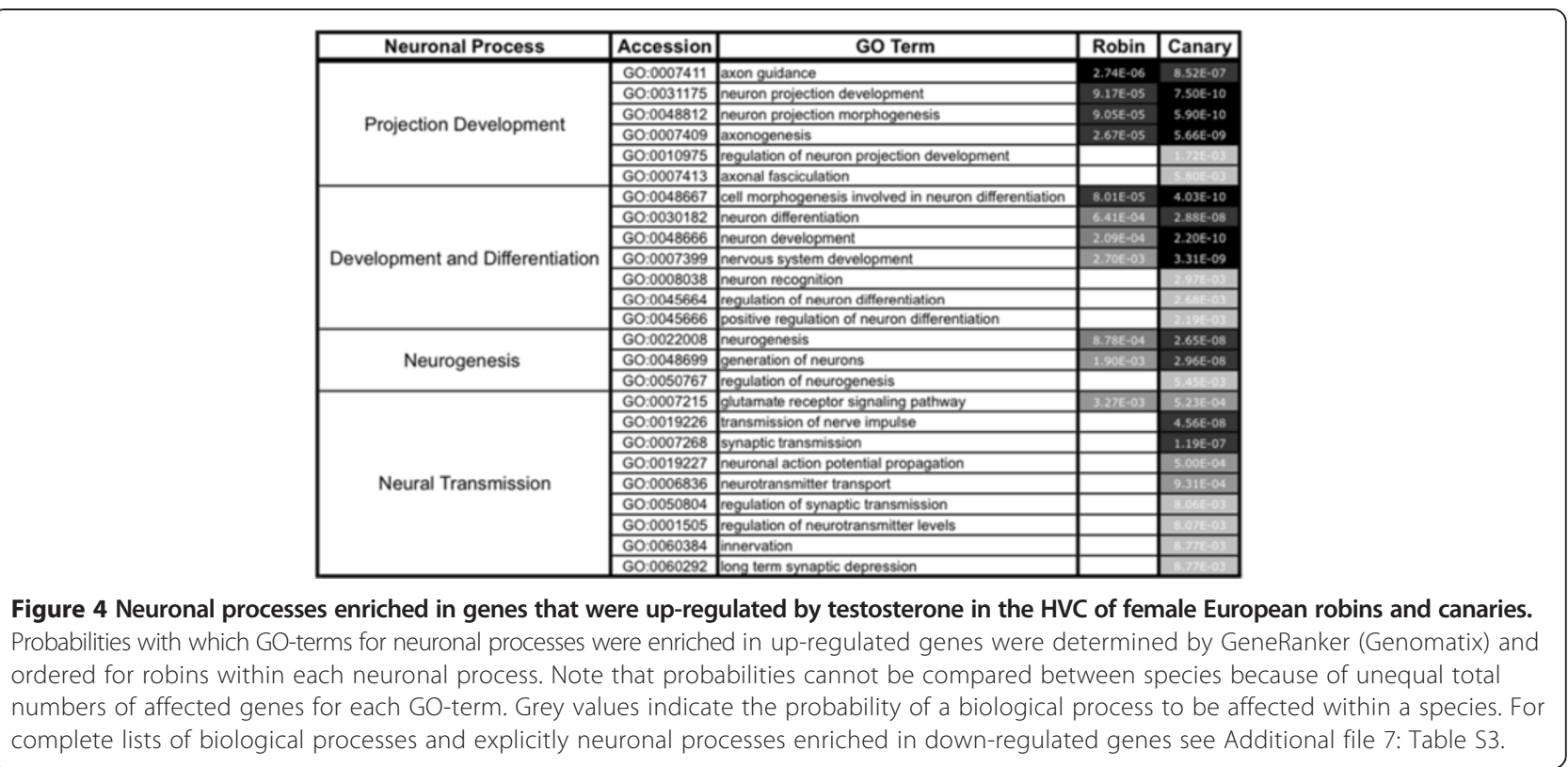

high probability only in the adult female HVC of canaries (Figure 4).

\section{Blood vessel development in the HVC of female robins}

Since transcriptome analysis revealed blood vessel development to be one of the most prominent effects of testosterone on the HVC of female robins, we investigated changes in the vascular bed in further detail. Using antilaminin immunostaining of HVC endothelial cells [57] we observed a testosterone-induced enlargement of microcapillaries in the HVC of female robins (Figure 5). The average luminal diameter was increased by about $50 \%$ after two weeks of testosterone treatment (mean \pm SEM: $5.06 \pm$ $0.05 \mu \mathrm{m}$ in controls and $7.51 \pm 0.36 \mu \mathrm{m}$ in testosterone females; Kruskal-Wallis Test, $\mathrm{n}=4$ for controls and 6 for testosterone females, $\mathrm{p}=0.0143$ ).

\section{Expression and putative roles of BDNF in the HVC}

Expression levels of BDNF as well as CADPS2 $\left(\mathrm{Ca}^{2+}\right.$ dependent activator protein for secretion 2) that enhance activity-dependent neuronal BDNF release [80] were increased in adult female robin $\mathrm{HVC}$ after testosterone treatment (Additional file 3: Table S1; Figure 6). Bibliographic analysis (BiblioSphere, Genomatix) of gene interactions in the group of up-regulated genes revealed BDNF to be one of the four major interactome hubs beside VEGFA, FN1 (fibronectin 1) and HMGCR (3-hydroxy-3methylglutaryl-CoA reductase). When we compared the testosterone-dependent transcriptome of the HVC between female robins and canaries, an up-regulation of BDNF expression turned out to be a common mechanism. Furthermore, the same response to testosterone was reported for the HVC of male Gambel's white- crowned sparrows (Zonotrichia leucophrys gambelii) [81] (Additional file 5: Figure S3B). In addition to BDNF, three neuropeptides (chromogranin B, CHGB; neuropeptide Y, NPY; urotensin 2 domain containing, UTS2D) and a neuropeptide-regulating protein (corticotropin releasing hormone binding protein, CRHBP) seem to be conserved mediators of testosterone effects on the HVC in both sexes.

Previous studies of the role of testosterone-induced BDNF in the canary HVC focused on the recruitment and survival of newborn neurons $[57,58]$. To elucidate putative functions of BDNF as a mediator of testosterone effects on the HVC of female robins, we performed bioinformatic analyses (using GePS and IPA) of potential BDNF target genes that we found to be regulated in our transcriptome experiments (Additional file 8: Table S4). The results consistently revealed glutamate signaling $\left(\right.$ GePS: $\mathrm{p}=10^{-4}$ ) or neurotransmission (IPA: $\mathrm{p}=10^{-6}$ ), cell differentiation (GePS: $\mathrm{p}=10^{-3}$; IPA: $\mathrm{p}=10^{-4}$ ) and fibroblast/connective tissue cell proliferation (GePS: $\mathrm{p}=10^{-4}$; IPA: $\mathrm{p}=10^{-3}$ ) to be affected by potential BDNF genes in the HVC of testosterone-treated female robins. We obtained a comparable picture when focusing on potential BDNF target genes that were regulated in the HVC of female canaries. However, we found the processes learning or memory (GePS: $\mathrm{p}=10^{-8}$ ) and regulation of apoptotic process/cell death $\left(\mathrm{p}=10^{-5}\right)$ to be affected by testosterone only in the HVC of female canaries and not in robins. Glutamatergic neurotransmission of female HVC cells might have been mediated by BDNF enhancing the expression of the ionotropic N-methyl-D-aspartate glutamate receptor 2A (GRIN2A), HOMER1 (homer homolog 1 (Drosophila)) that interacts with metabotropic glutamate receptors [82] and SV2B 

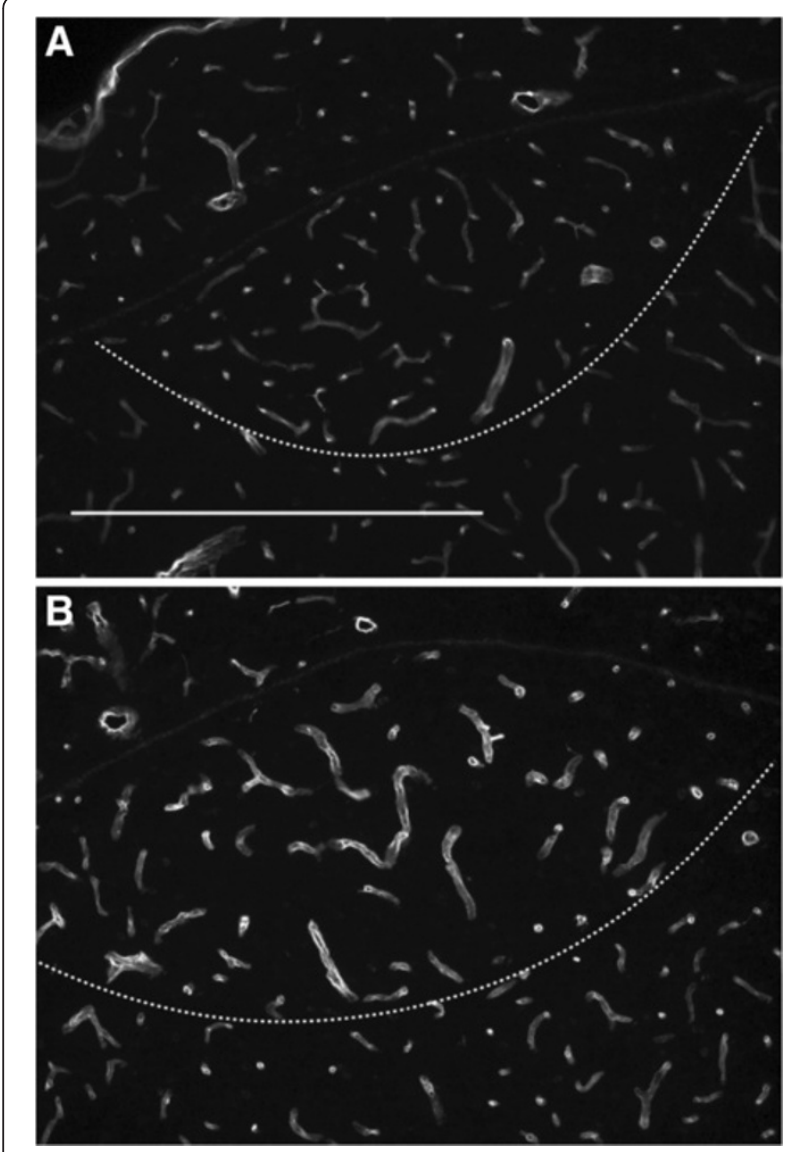

Figure $\mathbf{5}$ Testosterone stimulated the growth of the vascular bed in the HVC of female European robins. Photomicrographs of the HVC were prepared from control (A) and testosterone-treated (B) female robins and stained with an anti-laminin antibody. The ventral border of HVC was detected by a DAPI (4',6-diamidino-2phenylindole-dihydrochlorid) counterstain (data not shown) and is indicated by a dashed line; scale represents $500 \mu \mathrm{m}$.

(synaptic vesicle glycoprotein 2 b) that plays a role in glutamate release [83] in both female robins and canaries. We performed in situ hybridization experiments to examine our transcriptome results that showed stimulatory effects of testosterone on the expression of these genes in the HVC of female robins. Outcomes of all hybridization experiments turned out to be consistent with the transcriptome study (Figure 6). However, sample numbers were low, so that additional experiments would be necessary to confirm testosterone induced expression changes in the female robin $\mathrm{HVC}$ as detected by the microarray analysis.

\section{Discussion}

The singing activity of female European robins correlates with a naturally increased plasma testosterone level during the winter season [40]. In relation, song can be stimulated in female robins when endogenous plasma testosterone titers are low in spring [61] or in fall (this study) through a testosterone treatment. In the female canary, which has been the classical avian model for testosterone-induced song development, there is no evidence of a correlation between the plasma testosterone concentration and spontaneous female singing behavior. If anything, domesticated female canaries that sing spontaneously after the breeding season have lower plasma testosterone titers than breeding females [23]. Thus, use of female robins during the short day season is an alternative and novel approach to investigate physiological relevant testosterone effects on the song and song control system.

In female European robins captured in the fall, we observed an increase in soft song production within just a few days after the onset of testosterone administration while the time until occurrence of the first signs of full song varied considerably between birds. Different from robins, female canaries develop song under the influence of testosterone by progressively changing spectral features and temporal organization of notes [24,52,84] leading finally to the production of male-like song as in the case of the canaries of our study. Despite these differences in the effect of testosterone on singing behavior, we found European robins and canaries to share many neuroanatomical and gene expression changes in the song control system in response to experimental increases in testosterone levels. This congruence was all the more remarkable because in female robins we could not control for differences in features of the life history such as age and experience with the establishment of a winter territory.

An increase in the volume of the song control nuclei is one of the best-studied morphological effects of testosterone in female birds $[19,85]$ and occurs in the HVC and RA of females from both species. In light of testosterone effects on the HVC such as neuronal soma enlargement and retention of dense neurofilament immunostaining of less densely packed neurons, one would predict the oxygen and energy demands of the HVC to be enhanced. Consistent with this expectation, the expansion of the vascular bed in the $\mathrm{HVC}$ is a prominent early effect of a testosterone treatment in canaries $[51,56,57]$ and also occurred in female robins as shown in our transcriptome analysis and confirmed by anti-laminin immunostaining. Since angiogenesis requires the coordinated action of several cell types including neurons at the neurovascular interface [86], the differential regulation of some pleiotropic factors by testosterone could have reflected the complexity of the process of neurovascular congruence $[86,87]$. On a related note, TNFSF13B, the growth factor that showed the strongest up-regulation in the HVC of female robins in response to testosterone was described to be expressed by parenchymatic and perivascular astrocytes and assumed to play a role in the 


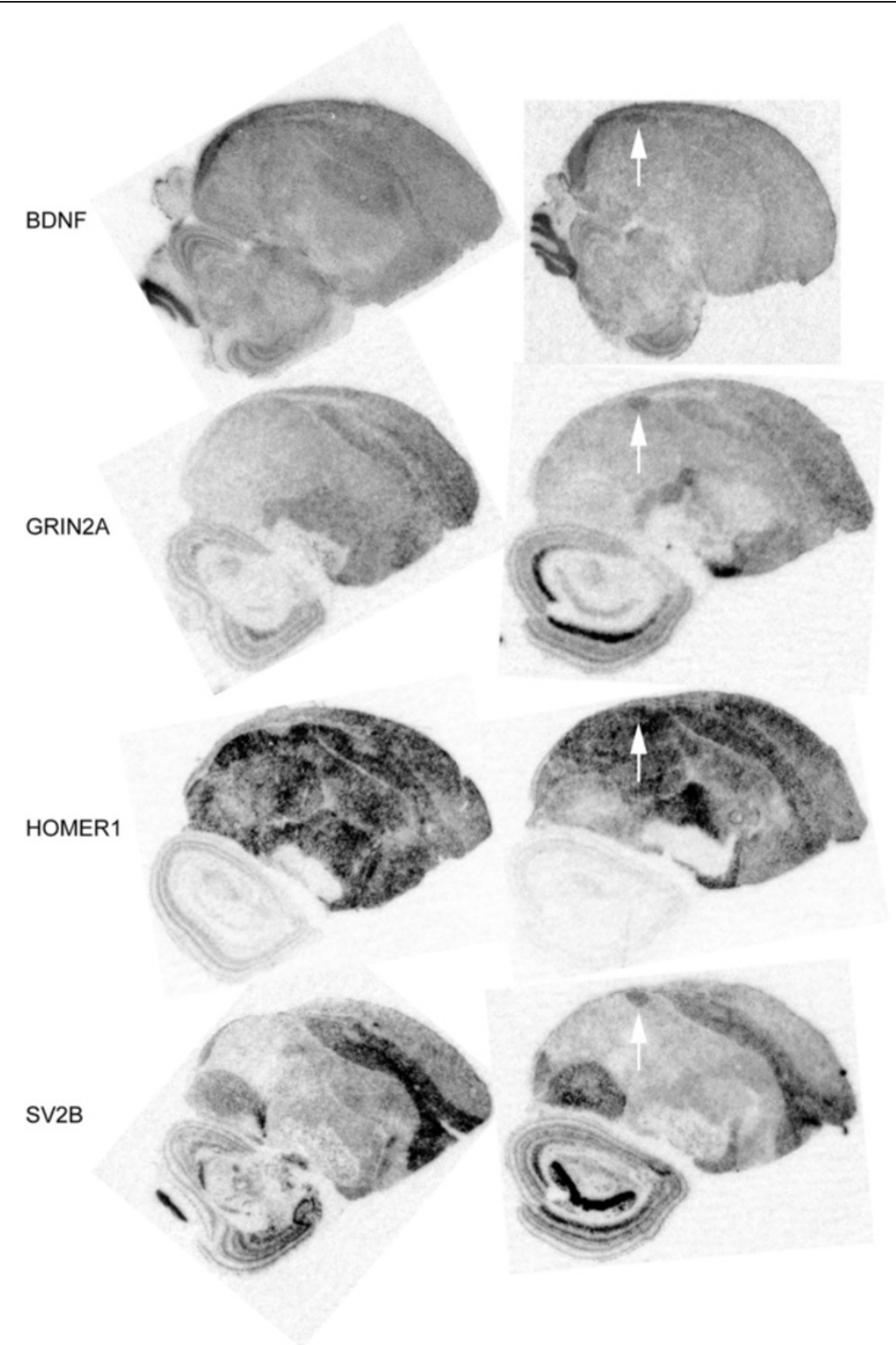

Figure 6 Testosterone stimulated the expression of BDNF and its potential target genes in the HVC of female European robins. Sagittal sections of control (left panels) and testosterone-treated (right panels) female robins were hybridized with radioactive antisense-probes for BDNF (brain-derived neurotrophic factor), and potential target genes of BDNF including the ionotropic glutamate receptor GRIN2A, HOMER1 that binds to metabotropic glutamate receptors and SV2B (synaptic vesicle glycoprotein 2b), respectively. Hybridized sections were exposed to an autoradiography film and the resulting autoradiographic images were scanned for documentation. For both groups images were representative for three (BDNF probe) and two birds (other probes), respectively. White arrows point to HVC.

development of a central humoral immune response [88]. Later TNFSF13B was identified to inhibit neuronal outgrowth as well [89].

Patterns of gene expression in the same brain region in songbirds can show large differences even among closely related species [90] and comparable physiological effects of a testosterone treatment can correlate with divergent changes in the gene expression in the medial amygdala and the hypothalamus of male versus female juncos [91]. Nevertheless, a comparison of testosterone- stimulated HVC transcriptomes of female robins, female canaries (this study for both) and male white-crowned sparrows [81] suggested that BDNF and potential BDNF target genes are conserved mediators of testosterone actions on the HVC of songbirds. Since BDNF expression is up-regulated during singing in the HVC of both male canaries [92] and zebra finches [93], the observed effects of testosterone on BDNF expression in the HVC of female robins could have been indirect, for example resulting from hormonal actions on genes that are responsible 
for enhanced song production, instead of being the result of a direct control of the BDNF gene expression by the activation of sex hormone receptors.

Roles of BDNF in the song control system were reported in the context of neurogenesis and anterograde trophic support by previously published studies. In the adult female canary endothelial BDNF promotes neuronal differentiation and out-migration of ventricular zone cells [57] as well as the recruitment and survival of newborn cells in HVC [50,56,59]. In male Gambel's white-crowned sparrows, the infusion of BDNF protein into RA increases cell soma size and decreases neuronal density [94]. In contrast to neurogenesis in female canaries, new neuron generation and recruitment in HVC turned out to be poorly stimulated by testosterone in female robins. While our pathway analysis of potential BDNF target genes that were regulated in the HVC supported a function of BDNF in the survival of newborn neurons in female canaries, similar processes were not detected in female robins using this subset of genes. However, in the female HVC of both robins and canaries locally acting BDNF most likely affected glutamatergic neurotransmission. By stimulating the expression of GRIN2A [95], a subunit of the NMDA glutamate receptor subtype, and HOMER1, a scaffold protein at the postsynaptic density that binds metabotropic glutamate receptors and modulates $\mathrm{Ca}^{2+}$ signaling [96], BDNF might have affected synaptic plasticity in HVC. An activity of BDNF that is different from recruitment and survival of newborn neurons that affects song is very likely to occur in the HVC of testosterone treated female canaries since BDNF-dependent singing of these birds precedes neuron recruitment [58].

Three potential target genes of BDNF that showed an increased expression level in the HVC of both female robins and canaries following a testosterone treatment are more strongly expressed in the HVC of testosteronetreated male Gambel's white-crowned sparrows [81] as well (Additional file 5: Figure S3B): HOMER1, SV2B and NPY. Thus, the increased expression of these genes seems to be a common response of $\mathrm{HVC}$ to testosterone that might be mediated by BDNF.

In females of many bird species, selection seems to have favored loss of song behavior [14]. In at least two families of European passerine birds, the Muscicapidae (i.a. the European robin) and the Fringillidae/Carduelidae (i.a. the canary) female song appears to be an ancestral character [13]. In our transcriptome studies we found several biological processes including blood vessel development/angiogenesis and neuronal projection development along with increased expression of diffusible mediators like BDNF to be common testosterone effects in the HVC of female robins and canaries. These changes in gene expression are in agreement with the stimulatory testosterone effect on singing activity and might be part of an ancestral response of the song control system to testosterone. However, there were also differences in the patterns of gene expression of the female HVC following testosterone treatment including enhanced neurotransmission and potential BDNF effects on learning or memory particularly in canaries, and a relatively low incidence of a regulation of gene networks related to neurogenesis in robins. Whether these differences in the gene expression pattern are related to species-specific effects of testosterone on song development needs further investigation.

Divergent testosterone treatment regimes in our experiments could have caused species differences in the state of song development on the day of sacrifice and might have contributed to differences in the HVC transcriptome between female robins and canaries. However, it is questionable whether a relatively weak manifestation of neurogenesis in the HVC of female robins compared to canaries was a consequence of shorter periods of testosterone treatment in most female robins. In male canaries it takes about a week for newborn neurons to become sedentary in HVC [97]. For comparison, the shortest survival time of female robins after testosterone implantation was seven days in our experiments.

Strongly increased female song in both species following testosterone treatment and increased neurotransmission in the HVC of female canaries but not in robins may indicate species-specific regulatory mechanisms of song. In female robins of our experiments, testosterone stimulated the production of a constant flow of low amplitude notes as quiet as soft song of males signaling aggressive intent in other bird species [98]. In contrast, female canaries that are treated with testosterone utter high amplitude male-like songs that are characterized by much higher syllable repetition rates and longer repetitions of identical syllables (tours) $[24,52,84]$ than any European robin song [45,99-101] (see also Additional file 1: Figure S1). Since HVC activity codes for the temporal order of song (for a review see [102]), the requirements for synaptic activity in HVC to produce testosterone-induced female song may be different between the two species. Strongly increased neurotransmission may be an essential testosterone effect to induce the temporal features of full song in female canaries, but dispensable for testosterone-stimulated song in female European robins. This observation justifies the assumption that testosterone-responsive mechanisms, which regulate song behavior in a bird species that was selectively bred for the elongation of tours [103], may not be involved in the stimulation of particular testosterone-responsive spontaneous song behaviors of wild bird species.

\section{Conclusions}

We identified neuron growth and spacing, angiogenesis and neuron projection morphogenesis to be testosteroneinduced effects in the HVC of female robins. Such cellular 
mechanisms of testosterone-induced HVC plasticity have already been described for the female canary, the model system for seasonal, sex hormone-dependent changes in bird song. While our transcriptome analysis of the female canary HVC revealed enhanced neurogenesis and synaptic transmission to be major neuronal responses to testosterone, the contribution of these processes to testosteroneinduced HVC plasticity in robins was less prominent. Following testosterone treatment, females from both species showed an increased transcription level of BDNF that is believed to play a role in the recruitment and survival of newborn HVC cells. We confirmed these BDNF functions in the canary HVC by pathway analysis of potential BDNF target genes that were up-regulated after testosterone treatment. In contrast, testosterone effects on glutamatergic neurotransmission that might have been mediated by BDNF occurred in the HVC of both female robins and canaries.

\section{Methods}

\section{Ethics statement}

Animal handling was carried out in accordance with the European Communities Council Directive 2010/63 EU and legislation of the state of Upper Bavaria. Ethical approval of the experimental research on birds was received from the Upper Bavaria Commission of 4 April 2011 in accordance with the advisory procedure referred to in Article 15 of the German Animal Welfare Act. The government of Upper Bavaria, "Sachgebiet 54 - Verbraucherschutz, Veterinärwesen, 80538 München" with the record number 55.2-1-54-2532-169-11 approved animal experiments.

\section{Animals and testosterone treatment}

Free-ranging European robin (Erithacus rubecula rubecula) females were collected by using ground traps during fall migration. Female canaries (Serinus canaria) were taken from the breeding facility of the Max Planck Institute for Ornithology and were part of a separate experiment examining the sex specificity of testosterone effects on the HVC in songbirds (M.-C. Ko et al., manuscript in preparation). Birds were housed individually in soundproofed recording boxes and song was recorded continuously as described in a previous study [104]. Birds were provided with water and food ad libitum while the artificial light cycle was adjusted weekly to natural conditions for sedentary robins. The canaries were kept on constant short day conditions (light: dark $=9.5: 14.5 \mathrm{~h}$ ). Blood samples were collected from the wing vein within five minutes after initial bird capture for sex determination by PCR using the primers P2 and P8 for the CHD1 alleles [105], and to determine testosterone plasma levels via radioimmunoassay as described in a previous study [106]. After recording the vocal activity of the birds for at least 14 days to determine individual baseline of singing activity, females were assigned randomly to either the testosterone (subcutaneous pellet; $1.5 \mathrm{mg}$; Innovative Research of America, USA) or control groups ( $n=6$ for all groups and both species).

Plasma testosterone levels from robins of both experimental groups were similar on the day of hormone pellet implantation (mean \pm SEM: $42 \pm 9 \mathrm{pg} / \mathrm{ml}$ for control birds vs $43 \pm 12 \mathrm{pg} / \mathrm{ml}$ for testosterone females; Kruskal-Wallis Test; $\mathrm{n}=6 ; \mathrm{p}=0.7445)$. In contrast, on the day of brain sampling plasma testosterone levels were significantly increased in the testosterone group as compared to the control group $(7509 \pm 1474 \mathrm{pg} / \mathrm{ml}$ for testosterone birds vs $29 \pm 5 \mathrm{pg} / \mathrm{ml}$ for controls; $\mathrm{p}=0.0045$ ). While testosterone levels of control female robins did not differ before and after treatment $(\mathrm{p}=0.4982)$, they did show significant increase in the testosterone group $(p=0.018)$. Thus, the experimental plasma level of testosterone was on average at least 7.5-fold increased compared to female robins living in the wild during the winter season (about 300-1000 pg/ml [40]). However, in testosteronetreated female canaries the plasma testosterone levels on the day of sacrifice were increased $(6960 \pm 1500 \mathrm{pg} / \mathrm{ml}$ for testosterone birds vs $108 \pm 67 \mathrm{pg} / \mathrm{ml}$ for controls) to an extent we observed in female robins.

\section{Song recordings}

Birds songs were continuously recorded and the sonograms of female robins were inspected daily to detect high amplitude song. Song files were analyzed using the Sound Analysis Pro software (http://soundanalysispro. $\mathrm{com} /$ ). Since female European robins display full song in the context of territory conflicts during the winter season [44], we did not expect full song to develop under the housing conditions of this study. However, the housing conditions allowed monitoring of any changes in vocal production when treated with testosterone and sacrificing the female robins at the onset of highamplitude note development. Experimental robins were sacrificed one day after we detected the first high amplitude notes with a frequency above $15 \mathrm{kHz}$ in a certain individual (on day 7, 8, 9, 12, 32 and 40, respectively). An individual of the control group was sacrificed on the same day to ensure a time-matched sampling of individuals from both groups. The above time point of sampling was chosen first, to minimize the period of isolation for these wild-caught birds, and second, because the conditions and time female robins required for development of full song was not known. Canary brains were taken after 5 weeks of testosterone treatment when songs were crystallized.

\section{Microarray analysis}

Birds were sacrificed by an overdose of isoflurane and brains were snap frozen on dry ice. Sagittal cryostat forebrain sections $(30-40 \mu \mathrm{m})$ obtained from testosterone-treated 
females and time-matched controls were mounted on cold glass slides and stored at $-80^{\circ} \mathrm{C}$. To collect tissues, slides were thawed quickly and fixed in ethanol at room temperature for 5 seconds; the HVC was identified under a stereo-microscope after the addition of a drop of RNasefree PBS due to its location, degree of myelination and cell sizes. HVC samples were dissected manually with titanium forceps and transferred into QIAzol (Qiagen). RNA isolation was performed on the Qiacube according the manufacturer's protocol for the Qiagen RNeasy Micro Kit (\# 74004) pursuing the optional DNA digest step and RNA quality was assessed by using the Agilent Model 2100 Bioanalyzer (Agilent Technologies, Palo Alto, CA). RNA concentrations were assessed using a Nanodrop 1000 spectrometer (Thermo Fisher Scientific, Wilmington USA) and 100 ng total RNA was processed for hybridization on the microarray using the Ambion WT Expression Kit (\# 4411974) and the Affymetrix WT Terminal Labeling and Controls Kit (\# 901524). The resulting cDNA was hybridized to the Custom Zebra finch Affymetrix Gene Chip ${ }^{\circ}$ MPIO-ZF1s520811 Exon Array for 16 hours at $45^{\circ} \mathrm{C}$ and $60 \mathrm{rpm}$ in the GeneChip Hybridization Oven 640. Samples from each bird were hybridized individually to separate arrays $(\mathrm{n}=6$ for canaries of both groups and testosteronetreated robins, and $n=5$ for control robins because the RNA extraction of the 9d control bird failed). Arrays were washed, stained and scanned using the Affymetrix GeneChip Fluidics Station 450 and Affymetrix GeneChip scanner 3000 7G. CEL files were generated by the Affymetrix $^{\circ}$ GeneChip $^{\circ}$ Command Console ${ }^{\circ}$ Software (AGCC) and the quality control for evaluating the success of individual hybridizations was assessed by the Affymetrix ${ }^{\circ}$ Expression Console ${ }^{\mathrm{Tt}}$ software.

Although the canary (Fringilidae) is more closely related to the zebra finch (Estrildidae) than the European robin (Muscicapidae) [107] and mean signal intensity was different between female European robins and canaries (mean \pm SEM: $6.6 \pm 0.02$ for robins and $7.18 \pm 0.01$ for canaries; Kruskal-Wallis Test, $\mathrm{p} \leq 0.001$ ), equal numbers of probes were detected above and below the threshold of significance for detection in the two species (above: $212799 \pm 1208$ for robins and $213776 \pm 416$ for canaries; below: $19874 \pm 1208$ for robins and $18897 \pm 416$ for canaries; $p>0.05$ ). Since quality of array hybridization was similar in both species differences in GO term enrichment were not due to technical reasons.

Affymetrix CEL files were imported into the software ChipInspector 2 (Genomatix) for normalization, fold change calculation and statistical evaluation (http://www.genomatix.de/ download/software/ChipInspector_Manual_V2) based on a single probe level [108]. Testosterone and control group were compared by probe wise division of the expression value of a testosterone-treated bird by expression values of all control birds. Mean expression data were analyzed using a minimum transcript coverage of 10-significant probes and a False Discovery Rate (FDR) set to zero. Genomic sequence differences were very unlikely to affect the detection of expression differences between species. Because on the array we were using any transcript was represented by several exon specific probe sets, and low probe coverage was sufficient for detection of transcript expression. Human orthologous gene IDs (g:Profiler, http://biit.cs.ut.ee/gprofiler/) of significantly affected genes were used for functional gene network analysis by publicly (g:Profiler; DAVID, http://david.abcc.ncifcrf.gov/) as well as commercially (GePS, BiblioSphere Pathway, Genomatix, Germany; IPA, Ingenuity Pathway Analysis, Ingenuity Systems, USA) available softwares $[109,110]$. In addition, we considered gene information obtained from PubMed (http://www. ncbi.nlm.nih.gov/pubmed) and GenCards (http://www. genecards.org/).

\section{Histological analyses}

To support selected findings of the transcriptome analysis from the $\mathrm{HVC}$ of female robins we performed histological analyses on $14 \mu \mathrm{m}$ forebrain sections that were obtained in parallel with the cryostat sections used for the microarray study. Thus, for each bird we produced several sets of sections that included thicker sections for the microarray analysis and singly mounted $14 \mu \mathrm{m}$ sections that were submitted to histological staining procedures and the in situ hybridization experiments, respectively. For verification and quantification of observations we made in birds of the microarray study we used HVC sections of female robins that obtained implants for two weeks $(n=4)$. Sections were mounted on SuperFrost microscope slides and Nissl and nuclear DAPI (4',6-diamidino-2-phenylindole-dihydrochlorid, Merck) stainings were performed following standard protocols. Approximate HVC volumes were calculated using Nissl-stained sections as the sum of the area sizes multiplied by the product of section interval and section thickness. To estimate cell spacing we determined the number of HVC cells in a defined area (1500 $\times$ 1500 pixel) of microscopic DAPI-images (32-fold magnification; 6 images per bird) with the help of ImageJ (http:// rsb.info.nih.gov/ij/). For immunostaining of HVC endothelium we used a rabbit polyclonal anti-Laminin antibody (Sigma, L9393) as the primary antibody diluted $1: 100$ in $1.9 \mathrm{mM} \mathrm{KH} \mathrm{PO}_{4}, 8.1 \mathrm{mM} \mathrm{Na} \mathrm{HPO}_{4} \times 7 \mathrm{H}_{2} \mathrm{O}, 150 \mathrm{mM}$ $\mathrm{NaCl}$ (pH 7.4) and $0.1 \%$ Triton X-100 (all Sigma) that was supplemented with $10 \%$ non-immune goat serum (Invitrogen). For immunostaining of HVC neurons primary antibodies were mouse monoclonal antibodies for NeuN (MAB377; 1:50) and Neurofilament (MAB5254; 1:200) (both Merck Millipore) diluted in $0.5 \mathrm{mM} \mathrm{NaH} \mathrm{PO}_{4} \times 2 \mathrm{H}_{2} \mathrm{O}$ (Sigma), $15 \mathrm{mM} \mathrm{Na}_{2} \mathrm{HPO}_{4} \times 7 \mathrm{H}_{2} \mathrm{O}, 250 \mathrm{mM} \mathrm{NaCl}$ (pH 7.4), $0.1 \%$ Triton X-100 and $10 \%$ non-immune goat serum. Secondary antibodies were goat IgGs conjugated with 
Alexa Fluor 488 (anti-rabbit) and 555 (anti-mouse) (both Invitrogen; 1:500), respectively. Fluorescent images were obtained with a LEICA DM 6000 B (Wetzlar, Germany) microscope. Luminal diameter of HVC microcapillaries was determined at 100 -fold magnification (Leica HCX PL APO 100x/NA1.4 oil immersion objective) with the help of the LEICA Image Manager. Both transversal and longitudinal capillary profiles were considered. To estimate the distribution of fluorescent antiNEFM signal in HVC microscopic images (40-fold magnification; 4 sections per bird) were obtained under identical conditions. With the help of ImageJ using default colour threshold settings we determined total area and area covered by anti-NEFM immunostaining.

In situ hybridizations were performed as described in a previous study [111]. RNA-probes specific to European robins were obtained by doing PCRs with adult male robin forebrain cDNA. Based on zebra finch sequence information PCR primers were designed for BDNF (NM_001048255.1; Fw: 5'-ATGACCATCCTTTTCTT TACTATG-3'; Rv: 5' - TCTTCCCCTTTTAATGGTC AATGTAC-3') and potential BDNF target genes like glutamate receptor, ionotropic, $\mathrm{N}$-methyl $\mathrm{D}$-aspartate 2A (GRIN2A; ENSTGUT00000004978; Fw: 5' -TGCAT CAGCCATGCTGGAAAA-3'; Rv: 5'-CATCACCCA GACAGAAGCACTA-3'), homer homolog 1 (Drosophila) (HOMER1; ENSTGUT00000003868; Fw: 5'-GCATGCT GTTACTGTGTCCTACT-3'; Rv: 5'-TGCTCATTCTGA CTTTTCTCCA-3') and synaptic vesicle glycoprotein 2B (SV2B; ENSTGUT00000008813; Fw: 5' -GCTGGCTGTG GTTTGGTTTAC-3'; Rv: 5' -GGCACCAAACTTGCAAA GCC-3'). The pCRII-TOPO vector (Life Technologies) was used to clone and sequence the RT-PCR products and to generate ${ }^{35} \mathrm{~S}$-CTP-labeled anti-sense probes. Processed slides were exposed to Biomax XAR film.

\section{Availability of supporting data}

Raw microarray data generated in this study have been deposited in the NCBI Gene Expression Omnibus (GEO). They are available for female European robins http:// www.ncbi.nlm.nih.gov/geo/query/acc.cgi?acc = GSE59203 and female canaries http://www.ncbi.nlm.nih.gov/geo/query/ acc.cgi?acc $=$ GSE59310. All other supporting data were included as additional files.

\section{Additional files}

Additional file 1: Figure S1. Small sections of soft song and full song notes from European robins. (A-E) Small sections from the continuous stream of notes of soft song (ss) and first high amplitude full song notes $(\mathrm{fs})$ are presented for the remaining five females (for songs of the sixth female see Figure 1 in the main text). (F) Small portion of full song from a male European robin. Sound waves (amplitude (analog/digital arbitrary units) over time (ms)) are shown in the upper panels and sonograms are presented in the lower panels (frequency $(\mathrm{Hz})$ over time $(\mathrm{ms})$ ).
Additional file 2: Figure S2. Nuclear stain of the HVC was used for estimate the testosterone effect on cell density in the HVC of female European robins. Photomicrographs are shown for the HVC of control (A - D) and testosterone-treated $(E-H)$ birds after staining with 4',6-Diamidino-2phenylindole dihydrochloride (DAPI) visualizing nuclear DNA. Arrows point at the epithelium of the collapsed lateral ventricle dorsal of HVC. The scale bar represents $500 \mu \mathrm{m}$.

Additional file 3: Table S1. Genes that were differentially expressed in the HVC of female European robins after testosterone treatment. Genes were identified by microarray analysis with the Custom Zebra finch Affymetrix Gene Chip ${ }^{\oplus}$ MPIO-ZF1s520811 and were listed as the human orthologous genes. (A) Lists of genes that were at least 1.6-fold up- or down-regulated. (B) Number of genes that showed the indicated fold change.

Additional file 4: Table S2. Genes that showed strong expression changes ( $\geq 2$-fold) after testosterone treatment in the HVC of female European robins. Genes were assigned to functional categories according to information obtained from PubMed (http//wwww.ncbi.nlm.nih.gov/pubmed) and GenCards (http://www.genecards.org/).

Additional file 5: Figure S3. Venn diagrams of genes differentially expressed in HVC after testosterone treatment. (A) Congruence of up- and down-regulated genes between female robins (red) and canaries (yellow). (B) Genes that were up-regulated in female European robins and canaries (both from this study), and in male white-crowned sparrows [81]. Symbols are given for genes that were up-regulated in the HVC of all three species and BDNF as well as potential BDNF target genes (Additional file 8: Table S4) are highlighted using bold letters.

Additional file 6: Figure S4. Genes that showed expression changes after testosterone treatment and are expected to play a role for the blood vessel development in the HVC of female European robins. (A) The largest network of up-regulated genes that we discovered by GePS (Genomatix) analysis included two angiogenic ligands (VEGFA, PGF). Further, (B) an association with angiogenic processes has been reported for most of the other genes of this network.

Additional file 7: Table S3. Enrichment of biological processes in genes that showed expression changes after testosterone treatment in the HVC of female European robins and canaries. Probabilities of biological processes enriched in ( $A, B)$ up- and $(C, D)$ down-regulated genes expressed in the HVC of robins $(A, C)$ and canaries $(B, D)$, respectively, were determined by GeneRanker (Genomatix). For (E) explicitly neuronal GO-terms were selected from the list of genes that were down-regulated in the HVC of female robins genes and grouped as shown for up-regulated genes in Figure 4 of the main text. For comparison probabilities of the same processes are also shown for female canaries. Enrichment of neuron projection development, neuron development/differentiation and neurogenesis in both up- and down-regulated genes suggested that these processes were dynamically affected following the testosterone treatment.

Additional file 8: Table S4. Potential BDNF target genes. (A) Potential BDNF target genes that were up- or down-regulated after testosterone treatment in the HVC of female robins. An asterisk indicates response to testosterone in the HVC of female canaries. (B) Additional potential BDNF target genes not affected by testosterone in the HVC of female robins HVC. For references that indicate BDNF-dependent changes in other species see the end of the document. As expected from the multiple cellular functions of BDNF the bioinformatic analysis (GePS; IPA) of all potential BDNF target genes revealed consistently cellular processes including neurotransmission and synaptic plasticity, regulation of cell death/apoptosis as well as cell growth, differentiation and proliferation.

\section{Abbreviations}

BDNF: Brain-derived neurotrophic factor; CADPS2: $\mathrm{Ca}^{2+}$-dependent secretion activator 2; DAPI: 4',6-diamidino-2-phenylindole; ECM: Extracellular matrix; GRIN: Glutamate receptor, ionotropic, N-methyl D-aspartate; Homer: Homer homolog (Drosophila); HVC: High vocal center; KDR: Kinase insert domain receptor; KITLG: KIT ligand; I/mMAN: Lateral/medial magnocellular nucleus of the anterior nicopallium; MET: Met proto-oncogene; NEFM: Neurofilament, medium polypeptide; PGF: Placental growth factor; RA: Robust nucleus of the arcopallium; SV2B: Synaptic vesicle glycoprotein 2B; VEGF: Vascular endothelial growth factor. 


\section{Competing interests}

The authors declare that they have no competing interests.

\section{Authors' contributions}

FD and MG designed the study; FD, CR, DG and MG performed the experiments; MH participated in cloning in situ hybridization probes; WG determined plasma hormone levels; FD and DG analyzed songs; FD, M-CK and CF-V analyzed the transcriptomes; FD and ATM performed the statistical analysis; FD and MG wrote the manuscript. All authors read and approved the final manuscript.

\section{Acknowledgements}

We thank Antje Bakker, Judith Kammerlander, Anja Lohrentz, Christina Reusch and Monika Trappschuh for technical assistance. We thank Lisa Gill and Drs. Albertine Leitao and Michaela Hau for critically reading earlier versions of the manuscript, and Joa Ahern-Seronde for its final editing.

\section{Disclosure statement}

We declare no conflict of interest with any financial organization regarding the material discussed in the manuscript.

Received: 15 July 2014 Accepted: 13 November 2014

Published online: 02 December 2014

\section{References}

1. Tramontin AD, Brenowitz EA: Seasonal plasticity in the adult brain. Trends Neurosci 2000, 23:251-258

2. Bolhuis JJ, Gahr M: Neural mechanisms of birdsong memory. Nat Rev Neurosci 2006, 7:347-357.

3. Gahr M, Metzdorf R: Distribution and dynamics in the expression of androgen and estrogen receptors in vocal control systems of songbirds. Brain Res Bull 1997, 44:509-517.

4. Nottebohm F, Arnold AP: Sexual dimorphism in vocal control areas of the songbird brain. Science 1976, 194:211-213.

5. Nottebohm F, Stokes TM, Leonard CM: Central control of song in the canary, Serinus canarius. J Comp Neurol 1976, 165:457-486.

6. Wild JM: Neural pathways for the control of birdsong production. J Neurobiol 1997, 33:653-670

7. Long MA, Fee MS: Using temperature to analyse temporal dynamics in the songbird motor pathway. Nature 2008, 456:189-194.

8. Aronov D, Veit L, Goldberg JH, Fee MS: Two distinct modes of forebrain circuit dynamics underlie temporal patterning in the vocalizations of young songbirds. J Neurosci 2011, 31:16353-16368.

9. Fujimoto H, Hasegawa T, Watanabe D: Neural coding of syntactic structure in learned vocalizations in the songbird. J Neurosci 2011, 31:10023-10033.

10. Bottjer SW, Miesner EA, Arnold AP: Forebrain lesions disrupt development but not maintenance of song in passerine birds. Science 1984, 224:901-903.

11. Langmore NE: Functions of duet and solo songs of female birds. Trends Ecol Evol 1998, 13:136-140.

12. Riebel K: The "mute" sex revisited: vocal production and perception learning in female songbirds. Adv Stud Behav 2003, 33:49-86.

13. Garamszegi LZ, Pavlova DZ, Eens M, Møller AP: The evolution of song in female birds in Europe. Behav Ecol 2007, 18:86-96.

14. Odom KJ, Hall ML, Riebel K, Omland KE, Langmore NE: Female song is widespread and ancestral in songbirds. Nat Commun 2014, 5:3379.

15. Leonard SL: Induction of singing in female canaries by injections of male hormone. Proc Soc Exp Biol Med 1939, 41:229-230.

16. Shoemaker HH: Effect of testosterone propionate on behavior of the female canary. Proc Soc Exp Biol Med 1939, 41:299-302.

17. Baldwin FM, Goldin HS, Metfessel M: Effects of testosterone propionate on female roller canaries under complete song isolation. Proc Soc Exp Biol Med 1940, 44:373-375.

18. Herrick EH, Harris JO: Singing female canaries. Science 1957, 125:1299-1300.

19. Nottebohm F: Testosterone triggers growth of brain vocal control nuclei in adult female canaries. Brain Res 1980, 189:429-436.

20. DeVoogd T, Nottebohm F: Gonadal hormones induce dendritic growth in the adult avian brain. Science 1981, 214:202-204.

21. Greenspon JM, Stein DG: Functional asymetry of the songbird brain: effects of testosterone on song control in adult female canaries (Serinus canarius). Neurosci Lett 1983, 41:125-131.
22. DeVoogd TJ, Nixdorf B, Nottebohm F: Synaptogenesis and changes in synaptic morphology related to acquisition of a new behavior. Brain Res 1985, 329:304-308.

23. Pesch A, Güttinger HR: Der Gesang des weiblichen Kanarienvogels. J Ornitho/ 1985, 126:108-110.

24. Vallet $\mathrm{E}$, Kreutzer M, Gahr M: Testosterone induces sexual release quality in the song of female canaries. Ethology 1996, 102:617-628.

25. Appeltants D, Ball GF, Balthazart J: Song activation by testosterone is associated with an increased carecholaminergic innervation of the song control system in female canaries. Neuroscience 2003, 121:801-814.

26. Thorpe WH: The learning of song patterns by birds, with especial reference to the song of the chaffinch (Fringilla coelebs). Ibis 1958, 100:535-570.

27. Kling JW, Stevenson-Hinde J: Development of song and reinforcing effects of song in female chaffinches. Anim Behav 1977, 25:215-220.

28. Thielcke-Poltz H, Thielcke G: Akustisches Lernen verschieden alter schallisolierter Amseln (Turdus merula L.) und die Entwicklung erlernter Motive ohne und mit künstlichem Einfluß von Testosteron. Z Tierpsychol 1960, 17:211-244.

29. Konishi M: Effects of deafening on song development in two species of juncos. Condor 1964, 66:85-102.

30. Konishi M: The role of auditory feedback in the control of vocalization in the white-crowned sparrow. Z Tierpsychol 1965, 22:770-783.

31. Kern MD, King JR: Testosterone-induced singing in female white-crowned sparrows. Condor 1972, 74:204-209.

32. Konishi M, Akutagawa E: Androgen increases protein synthesis within the avian brain vocal control system. Brain Res 1981, 222:442-446.

33. Baker MC, Bjerke TK, Lampe HU, Espmark YO: Sexual response of female yellowhammers to differences in regional song dialects and repertoire sizes. Anim Behav 1987, 35:396-401.

34. Arcese P, Stoddard PK, Hiebert SM: The form and function of song in female song sparrows. Condor 1988, 90:44-50.

35. Pavlova DZ, Pinxten $\mathrm{R}$, Eens $\mathrm{M}$ : Seasonal singing patterns and individual consistency in song activity in female European starlings (Sturnus vulgaris). Behaviour 2007, 144:663-680.

36. Hausberger M, Black JM: Female song in European starlings: the case of non-competitive song-matching. Ethol Ecol Evol 1991, 3:337-344.

37. Hausberger M, Henry L, Richard MA: Testosterone-induced singing in female European starlings (Sturnus vulgaris). Ethology 1995, 99:193-208.

38. De Ridder E, Pinxten R, Mees V, Eens M: Short- and long-term effects of male-like concentrations of testosterone on female European starlings (Sturnus vulgaris). Auk 2002, 119:487-497.

39. Sandel Ml: Exogenous testosterone increases female aggression in the European starling (Sturnus vulgaris). Behav Ecol Sociobiol 2007, 62:255-262.

40. Schwabl H: Winter and breeding territorial behaviour and levels of reproductive hormones of migratory European robins. Ornis Scand 1992, 23:271-276

41. Burkitt JP: A study of the robin by means of marked birds. Br Birds 1926, 20:91-101.

42. Lack D: The behaviour of the Robin. I. The life-history, with special reference to aggressive behaviour, sexual behaviour, and territory. II. A partial analysis of aggressive and recognitional behaviour. Proc Zool Soc London Ser A 1939, 109:169-219.

43. Lack D: The Life of the Robin. 4th edition. London: Collins Clear-Type Press; 1972.

44. East M: Time-budgeting by European robins Erithacus rubecula: Inter and intrasexual comparisons during autumn, winter and early spring. Ornis Scand 1982, 13:85-93.

45. Hoelzel AR: Song characteristics and response to playback of male and female Robins Erithacus rubecula. Ibis 1986, 128:115-127.

46. Bottjer SW, Schoonmaker JN, Arnold AP: Auditory and hormonal srimulation interact to produce neural growth in adult canaries. J Neurobiol 1986, 17:605-612.

47. Brenowitz EA, Arnold AP: The effects of systemic androgen treatment on androgen accumulation in song control regions of the adult female canary brain. J Neurobiol 1990, 21:837-843.

48. Bottjer SW, Maier E: Testosterone and the incidence of hormone target cells in song-control nuclei of adult canaries. J Neurobiol 1991, 22:512-521.

49. Brown SD, Bottjer SW: Testosterone-induced changes in adult canary brain are reversible. J Neurobiol 1993, 24:627-640.

50. Rasika S, Nottebohm F, Alvarez-Buylla A: Testosterone increases the recruitment and/or survival of new high vocal center neurons in adult female canaries. Proc Natl Acad Sci U S A 1994, 91:7854-7858. 
51. Goldman SA, Nottebohm F: Neuronal production, migration, and differentiation in a vocal control nucleus of the adult female canary brain. Proc Natl Acad Sci U S A 1983, 80:2390-2394

52. DeVoogd TJ: Steroid interactions with structure and function of avian song control regions. J Neurobiol 1986, 17:177-201.

53. Bottjer SW, Dignan TP: Joint hormonal and sensory stimulation modulate neuronal number in adult canary brains. J Neurobiol 1988, 19:624-635.

54. Johnson F, Bottjer SW: Hormone-induced changes in identified cell populations of the higher vocal center in male canaries. J Neurobio/ 1993, 24:400-418.

55. Yamamura T, Barker JM, Balthazart J, Ball GF: Androgens and estrogens synergistically regulate the expression of doublecortin and enhance neuronal recruitment in the song system of adult female canaries. J Neurosci 2011, 31:9649-9657.

56. Chen Z, Ye R, Goldman SA: Testosterone modulation of angiogenesis and neurogenesis in the adult songbird brain. Neuroscience 2013, 239:139-148.

57. Louissaint A Jr, Rao S, Leventhal C, Goldman SA: Coordinated interaction of neurogenesis and angiogenesis in the adult songbird brain. Neuron 2002, 34:945-960.

58. Hartog TE, Dittrich F, Pieneman AW, Jansen RF, Frankl-Vilches C, Lessmann V, Lilliehook C, Goldman SA, Gahr M: Brain-derived neurotrophic factor signaling in the HVC is required for testosterone-induced song of female canaries. J Neurosci 2009, 29:15511-15519.

59. Rasika S, Alvarez-Buylla A, Nottebohm F: BDNF mediates the effects of testosterone on the survival of new neurons in an adult brain. Neuron 1999, 22:53-62.

60. Hall ZJ, MacDougall-Shackelton SA: Influence of testosterone metabolites on song-control system neuroplasticity during photostimulation in adult European starlings (Sturnus vulgaris). PLoS One 2012, 7:e40060

61. Kriner $\mathrm{E}$, Schwabl H: Control of winter song and territorial aggression of female robins (Erithacus rubecula) by testosterone. Ethology 1991, 87:37-44

62. Fusani L, Metzdorf R, Hutchison JB, Gahr M: Aromatase inhibition affects testosterone-induced masculinization of song and the neural song system in female canaries. J Neurobiol 2003, 54:370-379.

63. Lovell PV, Clayton DF, Replogle KL, Mello CV: Birdsong "transcriptomics": neurochemical specializations of the oscine song system. PLoS One 2008, 3:e3440.

64. Luine V, Nottebohm F, Harding C, McEwen BS: Androgen affects cholinergic enzymes in syringeal motor neurons and muscle. Brain Res 1980, 192:89-107.

65. Harding CF, Sheridan K, Walters MJ: Hormonal specificity and activation of sexual behavior in male zebra finches. Horm Behav 1983, 17:111-133.

66. Bleisch W, Luine VN, Nottebohm F: Modification of synapses in androgensensitive muscle. I. Hormonal regulation of acetylcholine receptor number in the songbird syrinx. J Neurosci 1984, 4:786-792

67. Wade J, Buhlman L, Swender D: Post-hatching hormonal modulation of a sexually dimorphic neuromuscular system controlling song in zebra finches. Brain Res 2002, 929:191-201.

68. Shibuya M: Unique signal transduction of the VEGF family members VEGR-A and VEGF-E. Biochem Soc Trans 2009, 37:1161-1166.

69. Geretti E, Shimizu A, Klagsgrun M: Neuropilin structure governs VEGF and semaphorin binding and regulated angiogenesis. Angiogenesis 2008 , 11:31-39.

70. Van Belle E, Witzenbichler B, Chen D, Silver M, Chang L, Schwall R, Isner JM: Potentiated angiogenic effect of scatter factor/hepatocyte growth factor via induction of vascular endothelial growth factor: the case for paracrine amplification of angiogenesis. Circulation 1998, 97:381-390.

71. Abounader R, Laterra J: Scatter factor/hepatocyte growth factor in brain tumor growth and angiogenesis. Neuro Oncol 2005, 7:436-451.

72. Lobov IB, Rao S, Carroll TJ, Vallance JE, Ito M, Ondr JK, Kurup S, Glass DA, Patel MS, Shu W, Morrisey EE, McMahon AP, Karsenty G, Lang RA: WNT7b mediates macrophage-induced programmed cell death in patterning of the vasculature. Nature 2005, 437:417-421.

73. Okano H, Shiraki K, Yamanaka Y, Inoue H, Kawakita T, Saitou Y, Yamaguchi Y, Enokimura N, Ito K, Yamamoto N, Sugimoto K, Murata K, Nakano T: Functional expression of a proliferation-related ligand in hepatocellular carcinoma and its implications for neovascularization. World J Gastroenterol 2005, 11:4650-4654

74. Stenman JM, Rajagopal J, Carroll TJ, Ishibashi M, McMahon J, McMahon AP: Canonical Wnt signaling regulates organ-specific assembly and differentiation of CNS vasculature. Science 2008, 322:1247-1250.
75. Daneman R, Agalliu D, Zhou L, Kuhnert F, Kuo CJ, Barres BA: Wnt/ß-catenin signaling is required for CNS, but not non-CNS, angiogenesis. Proc Natl Acad Sci U S A 2009, 106:641-646.

76. Kleaveland B, Zheng X, Liu JJ, Blum Y, Tung JJ, Zou Z, Sweeney SM, Chen M, Guo L, Lu M, Zhou D, Kitajewski J, Affolter M, Ginsberg MH, Kahn ML: Regulation of cardiovascular development and integrity by the heart of glass-cerebral cavernous malformation protein pathway. Nat Med 2009, 15:169-176.

77. Shellenberger TD, Wang M, Gujrati M, Jayakumar A, Strieter RM, Burdick MD, loannides CG, Efferson CL, El-Naggar AK, Roberts D, Clayman GL, Frederick MJ: BRAK/CXCL14 is a potent inhibitor of angiogenesis and a chemotactic factor for immature dendritic cells. Cancer Res 2004, 64:8262-8270.

78. N-h G, Krutzsch HC, Inman JK, Roberts DD: Thrombospondin 1 and type I repeat peptides of thrombospondin 1 specifically induce apoptosis of endothelial cells. Cancer Res 1997, 57:1735-1742.

79. Rege TA, Stewart J Jr, Dranka B, Benveniste EN, Silverstein RL, Gladson CL: Thrombospondin-1-induced apoptosis of brain microvascular endothelial cells can be mediated by TNF-R1. J Cell Physio/ 2009, 218:94-103.

80. Sadakata T, Mizoguchi A, Sato Y, Katoh-Semba R, Fukuda M, Mikoshiba K, Furuichi T: The secretory granule-associated protein CAPS2 regulates neurotrophin release and cell survival. J Neurosci 2004, 24:43-52.

81. Thompson CK, Meitzen J, Replogle K, Drnevich J, Lent KL, Wissman AM, Farin FM, Bammler TK, Beyer RP, Clayton DF, Perkel DJ, Brenowitz EA: Seasonal changes in patterns of gene expression in avian song control brain regions. PLoS One 2012, 7:e35119.

82. Brakeman PR, Lanahan AA, O'Brien R, Roche K, Barnes CA, Huganir RL, Worley PF: Homer: a protein that selectively binds metabotropic glutamate receptors. Nature 1997, 386:284-288.

83. Bragina L, Fattorini G, Giovedí S, Melone M, Bosco F, Benfenati F, Conti F: Analysis of synaptotagmin, SV2, and Rab3 expression in cortical glutamatergic and GABAergic axon terminals. Front Cell Neurosci 2012, 5:32.

84. Vellema M: So you think you can sing; a study on seasonal and hormone regulated plasticity in the brain and behavior of songbirds. In PhD thesis. Antwerp Universiteit; 2012

85. Brenowitz EA: Plasticity of the adult avian song control system. Ann N Y Acad Sci 2004, 1016:560-585.

86. Lee HS, Han J, Bai HJ, Kim KW: Brain angiogenesis in development and pathological processes: regulation, molecular and cellular communication at the neurovascular interface. FEBS Lett 2009, 276:4622-4635.

87. Fantin $\mathrm{A}$, Maden $\mathrm{CH}$, Ruhrberg C: Neuropilin ligands in vascular and neuronal patterning. Biochem Soc Trans 2009, 37:1228-1232.

88. Krumbholz M, Theil D, Derfuss T, Rosenwald A, Schrader F, Monoranu CM Kalled SL, Hess DM, Serafini B, Aloisi F, Wekerle H, Hohlfeld R, Meinl E: BAFF is produced by astrocytes and up-regulated in multiple sclerosis lesions and primary central nervous system lymphoma. J Exp Med 2005, 201:195-200.

89. Zhang L, Zheng S, Wu H, Wu Y, Liu S, Fan M, Zhang J: Identification of BLys (B Lymphocyte Stimulator), a non-myelin-associated protein, as a functional ligand for Nogo-66 receptor. J Neurosci 2009, 29:6348-6352.

90. Drnevich J, Replogle KL, Lovell P, Hahn TP, Johnson F, Mast TG, Nordeen E, Nordeen K, Strand C, London SE, Mukai M, Wingfield JC, Arnold AP, Ball GF, Brenowitz EA, Wade J, Mello CV, Clayton DF: Impact of experiencedependent and -independent factors on gene expression in songbird brain. Proc Natl Acad Sci U S A 2012, 109(Suppl 2):17245-17252.

91. Peterson MP, Rosvall KA, Choi JH, Ziegenfus C, Tang H, Colbourne JK, Ketterson ED: Testosterone affects neural gene expression differently in male and female juncos: a role for hormones in mediating sexual dimorphism and conflict. PLoS One 2013, 8:e61784.

92. Li XC, Jarvis ED, Alvarez-Borda B, Lim DA, Nottebohm F: A relationship between behavior, neurotrophin expression, and new neuron survival. Proc Natl Acad Sci U S A 2000, 97:8584-8589.

93. Wada K, Howard JT, McConnell P, Whitney O, Lints T, Rivas MV, Horita H, Patterson MA, White SA, Scharff C, Haesler S, Zhao S, Sakaguchi H, Hagiwara M, Shiraki T, Hirozane-Kishikawa T, Skene P, Hayashizaki Y, Carninci P, Jarvis ED: A molecular neuroethological approach for identifying and characterizing a cascade of behaviorally regulated genes. Proc Natl Acad Sci U S A 2006, 103:15212-15217.

94. Wissman AM, Brenowitz EA: The role of neurotrophins in the seasonal-like growth of the avian song control system. J Neurosci 2009, 29:6461-6471.

95. Foster KA, McLaughlin N, Edbauer D, Phillips M, Bolton A, Constantine-Paton M, Sheng M: Distinct roles of NR2A and NR2B cytoplasmic tails in long-term potentiation. J Neurosci 2010, 30:2676-2685. 
96. Jardin I, López JJ, Berna-Erro A, Salido GM, Rosado JA: Homer proteins in $\mathrm{Ca}^{2+}$ entry. IUBMB Life 2013, 65:497-504.

97. Kirn JR, Fishman Y, Sasportas K, Alvarez-Buylla A, Nottebohm F: Fate of new neurons in adult canary high vocal center during the first 30 days after their formation. J Comp Neurol 1999, 411:487-494.

98. Anderson RC, Searcy WA, Hughes M, Nowicki S: The receiver-dependent cost of soft song: a signal of aggressive intent in songbirds. Anim Behav 2012, 83:1443-1448.

99. Stock M, Bergmann HH: The song of the robin (Erithacus rubecula superbus) from Tenerife (Canarian Islands) - structure and reactions to playback. Zool JB Physiol 1988, 92:197-212.

100. Dabelsteen T, McGregor PK, Holland J, Tobias JA, Pedersen SB: The signal function of overlapping singing in male robins. Anim Behav 1997, 53:249-256.

101. Dabelsteen T, McGregor PK, Lampe HM, Langmore NE, Holland JO: Quiet song in song birds: an overlooked phenomenon. Bioacoustics 1998, 9:89-105.

102. Fee MS, Long MA: Neural mechanisms underlying the generation of birdsong: a modular sequential behavior. In Birdsong, Speech, and Language: Exploring the Evolution of Mind and Brain. Edited by Bolhuis JJ, Everaert M. Cambridge: MIT Press; 2013:353-377.

103. Güttinger HR: Consequences of domestication on the song structures in the canary. Behaviour 1985, 94:254-278.

104. Dittrich F, Feng Y, Metzdorf R, Gahr M: Estrogen-inducible, sex-specific expression of brain-derived neurotrophic factor mRNA in a forebrain song control nucleus of the juvenile zebra finch. Proc Natl Acad Sci U S A 1999, 96:8241-8246.

105. Griffiths R, Double MC, Orr K, Dawson RJ: A DNA test to sex most birds. Mol Ecol 1998, 7:1071-1075.

106. Goymann W, Trappschuh M, Jensen W, Schwabl I: Low ambient temperature increase food intake and dropping production, leading to incorrect estimates of hormone metabolite concentrations in European stonechats. Horm Behav 2006, 49:644-653.

107. Johansson US, Fjeldså J, Bowie RC: Phylogenetic relationships within Passerida (Aves: Passeriformes): a review and a new molecular phylogeny based on three nuclear intron markers. Mol Phylogenet Evol 2008, 48:858-876.

108. Cohen CD, Lindenmeyer MT, Eichinger F, Hahn A, Seifert M, Moll AG, Schmid H, Kiss E, Gröne E, Gröne HJ, Kretzler M, Werner T, Nelson PJ: Improved elucidation of biological processes linked to diabetic nephropathy by single probe-based microarray data analysis. PLoS One 2008, 3:e2937.

109. Michelhaugh SK, Lipovich L, Blythe J, Jia H, Kapatos G, Bannon MJ: Mining Affymetrix microarray data for long non-coding RNAs: altered expression in the nucleus accumbens of heroin abusers. J Neurochem 2011, 116:459-466.

110. Sharad S, Srivastava A, Ravulapalli S, Parker P, Chen Y, Li H, Petrovics G, Dobi A: Prostate cancer gene expression signature of patients with high body mass index. Prostate Cancer Prostatic Dis 2011, 14:22-29.

111. Voigt C, Metzdorf R, Gahr M: Differential expression pattern and steroid hormone sensitivity of SNAP-25 and synaptoporin mRNA in the telencephalic song control nucleus HVC of the zebra finch. J Comp Neurol 2004, 475:83-94.

doi:10.1186/s12868-014-0128-0

Cite this article as: Dittrich et al:: Regulatory mechanisms of testosterone-stimulated song in the sensorimotor nucleus HVC of female songbirds. BMC Neuroscience 2014 15:128.

\section{Submit your next manuscript to BioMed Central and take full advantage of:}

- Convenient online submission

- Thorough peer review

- No space constraints or color figure charges

- Immediate publication on acceptance

- Inclusion in PubMed, CAS, Scopus and Google Scholar

- Research which is freely available for redistribution

Submit your manuscript at www.biomedcentral.com/submit
( Biomed Central 